\title{
An Analysis on Extent of Integration and the Speed of Adjustment of Price for Equilibrium and Impulse Response Function in Major Vegetable Markets in West Bengal, India
}

\author{
Prasenjit Kundu ${ }^{1}$, Nayan Kishor Adhikary ${ }^{2}$, \\ Arindam Banerjee ${ }^{1}$ and Tapan Mandal ${ }^{2}$ \\ ${ }^{1}$ Sasya Shyamala Krishi Vigyan Kendra, Ramakrishna Mission Vivekananda University, \\ Narendrapur - 700103, West Bengal, India \\ ${ }^{2}$ Institute of Agricultural Science, University of Calcutta, 51/2, Hazra Road, \\ Kolkata - 700019, West Bengal, India \\ *Corresponding author
}

A B S T R A C T

\begin{tabular}{|l|}
\hline K e y w o r d s \\
Integration, \\
Impulse, Speed of \\
adjustment, \\
Marketing, \\
Stationary \\
\hline Article Info \\
\hline $\begin{array}{l}\text { Accepted: } \\
\text { 10 July 2020 } \\
\text { Available Online: } \\
\text { 10 August } 2020\end{array}$ \\
\hline
\end{tabular}

\section{Introduction}

There has been increasing concern in recent years regarding the efficiency of marketing of different vegetables in India. It is believed that poor efficiency in the marketing channels and poor marketing infrastructure leads to high fluctuation in consumer prices and only a small share of the consumer rupee reaches to the producer farmers. The huge geographical area and myriad of agro-climatic situations permit the whole country to exert a strong influence especially in supply of most of the agricultural commodities. It can be entirely true for the vegetable crops due to its shorter growth periods and wide ecological amplitude 
as compared to many other crops. These type of variations in the output of these crops resulted in lead to wild fluctuations in their prices not only that it also exposing the vegetable growers to more risk as compared to the growers of other crops. Contemporarily it can be opined that, horticulture based diversification also responsible for another set of marketing-related problems. The lack of market intelligence about the potential markets and the pattern of market arrivals and prices

in important regional and national markets further add to the woes of the growers. Therefore, the requirement of proper and adequate marketing intelligence system has been felt and raised from time to time by many scientists (Kalloo and Pandey, 2002; Rai and Pandey, 2004; Singh et al., 2004). Murthi and Shikamany (2007) have observed that an efficient marketing system can reduce post harvest losses, promote graded processing, packaging services and food safety practices that include demand driven production which enables high value addition to exports. As a result of the large number of intermediaries in the channel and high cost of transportation, both producers and consumers are not benefited.

Market integration is defined as a situation in which arbitrage causes prices in different markets to move together (Behura and Pradhan, 1998). The long run relationship between prices of different spatially separated markets can be studied though integration analysis. Goodwin and Schroeder (1991) studied the co-integration relation among prices in regional markets.

The authors used Engle and Granger test to study the co-integration found that markets separated by long distances had lower degrees of integration than close proximity markets. Nawadkar (2005) revealed that the commission charges, transportation cost and packaging material cost were the major components of marketing cost and the producer received good prices in terminal markets in spite of high marketing cost because of a better price.

In India, West Bengal is the largest producer of vegetables. In West Bengal 1.31 million hectares area is under vegetable cultivation which yields 22.4 million MT of vegetables in 2017-2018. South 24 Parganas play an important role in the vegetable market scenario. Market arrivals of vegetables have shown significant increase in the recent years and expected to accelerate further in coming years. State Marketing Regulation Act have been passed by the West Bengal Government and the State has formulated by-laws for regulating market practices as per the Act. Against this backdrop, the present study was undertaken to gain insights into the behaviour pattern of market arrivals and wholesale prices of important vegetable crops (Tomato, Cauliflower, Cabbage, Chili, Cucurbits and Brinjal) in some selected well equipped, furnished markets of the vegetable of selected blocks of South 24 Parganas district of West Bengal. Therefore in this study an attempt has been made to know the degree of integration and speed of adjustment of price for equilibrium and impulse response function between different Agricultural produce marketing committee markets of South 24 Parganas district. This would help policy makers to devise options to safeguard the interest of the all stakeholder's viz., Farmers, traders and consumers.

\section{Materials and Methods}

The process of selecting the study area, details about the study area, data collection methodology and analytical techniques which helps us to attain the objectives of the study. 


\section{Selection of study area}

West Bengal as well as the Eastern part of India is producing the vegetable in a mammoth amount since last decades. Both the traditional as well as the new modern technologies are used for the intensified growth of vegetable sector in this region. South 24 Parganas district has been selected purposively for its normal average yield per acreage area in case of vegetable production. From South24 Parganas district, five blocks were selected purposively. The selected blocks were Budge Budge-I, Baruipur, Bhangore-II, Diamond Harbour-I and Falta.

\section{Sampling design}

The center of the study was on the input and output data of vegetables as well as the arrivals of the quantity of product in the market and the prices of the produce throughout the year obtained from the respondents of the selected market areas of 5 blocks. Multistage sampling design was used for the identification of the respondents. South 24 Parganas district of West Bengal was selected purposively at first in this technique. Two markets were nominated from each block of South 24 Parganas (Mallikpur and Notunhaat market from Budge Budge-I block, Baruipur, Surjapur from Baruipur block, Charu Market, Bhangore-II from Bhangore-II block, Basul Danga Haat and Diamond Harbour-Istation road bazar from Diamond Harbour-I block and Sohsorar haat and Fatepur from Falta block) based on the size of the vegetable markets. In the fourth full stage, 30 respondents were selected from the each market with 20 producers, 5 wholesalers and 5 retailers (Table 1).

\section{Type and source of data}

For achieving the purposes of the work the primary along with secondary data in quantitative and qualitative nature was collected. Primary records was prevailed from the respondents through personal interview on the basis of the pre structured survey schedule.

\section{Tabulation}

After collection of the survey data the further step was to process the raw figures and arrange them in a tabular form in excel sheet. The collected data were transferred under different heads of separate square sheets with respect of different size groups. Subsequently different tables were prepared with different goals to achieve the objectives of the studies. The entire information of the survey was presented with a view to provide a base for purposeful analysis and interpretation of the findings.

\section{Data source}

For the present study, the secondary data have been collected and used from different secondary sources, viz., (1) West Bengal State Marketing Board (2) Statistical Abstract of West Bengal (3) National Horticultural Database (4) Directorate of marketing and inspection, Government of India. From the above sources the data on prices of different vegetables viz., Brinjal, Chili, Cucurbits, Tomato, Cauliflower and Cabbage have been collected from different markets of various blocks for the period 2017 and 2018.

\section{Analytical framework}

The variables are said to be integrated if there exists a stationary linear combination of nonstationary random variables. In a model which includes two such variables it is possible to choose coefficients which make yt- $\alpha-\beta \mathrm{xt}$ appear to be stationary. But such an empirical result tells little of the short run relationship between yt and $x t$. To be a long run 
relationship between the variables they must be co-integrated. The following cases illustrate the discussion. One can examine yt and xt I (1) i.e., whether or not they contain unit roots provided they are both I (1), and estimate the parameters of the co-integration relation $\mathrm{yt}=\beta 0+\beta 1 \times 2+\mu \mathrm{t}$ and test whether the least squares residual ut appears to be I (0) or not.

\section{Augmented Dickey Fuller (ADF) Test for Unit Root test}

To illustrate the use of Dickey-Fuller test, consider first an AR (1) Process:

$\mathrm{Yt}=\mu+$ pyt $-1+\varepsilon 1$

Where $\mu$ and $\mathrm{p}$ are parameters and $\varepsilon$ is assumed to be white noise for stationary series $y$ if $-1<p<1$. If the absolute value of $p$ is greater than one, the series is explosive. Therefore, the hypothesis of stationary series can be evaluated by testing whether the absolute value of $p$ is strictly less than one.

\section{Johansson's co-integrations test}

After the confirmation of the unit Roots, there was a need to test the integration of the markets. Given a group of non-stationary series, it is to be determined whether the series are co-integrated and if they are in identifying the co-integration (long-run equilibrium) relationships, the test under Vector Auto regression method with the help of Johansson's Co- integration Test was carried out. The VAR approach sidesteps the need for structural modeling by modeling every endogenous variables in the system as a function of the lagged values of all of the endogenous variables in the system.

The mathematical form of a VAR is:

$\mathrm{Yt}=\mathrm{A} 1 \mathrm{yt}-1+\ldots \ldots \ldots \ldots \ldots \ldots \ldots \ldots \ldots \ldots . .+$ A1yt-p $+\mathrm{Bxt}^{+} \varepsilon 1$ Where, Yt $=\mathrm{k}$ vector of endogenous variables,

$\mathrm{Xt}=\mathrm{d}$ vector of endogenous variables, $\mathrm{A} 1, \ldots ., \mathrm{Ap}$ and $\mathrm{B}$ are matrices of coefficients to be estimated, and

$\varepsilon 1=$ vector of innovations that may be contemporaneously correlated with each other but are uncorrelated with their own lagged values.

\section{Speed of adjustment}

For efficient marketing price equilibrium in the market is always desirable but because of inelastic demand and supply of vegetables leads to very high fluctuation in the prices among vegetable markets. Here an attempt has been made to estimate the speed of adjustment of price for equilibrium.

$$
\begin{array}{ll}
\mathrm{K}_{\mathrm{t}}=\mathrm{a}_{1}+\mathrm{a}_{2} \mathrm{~S}_{\mathrm{t}}+\mathrm{e}_{\mathrm{t}} & \mathrm{K}_{\mathrm{t}}=\text { price of Bhangore-II market at period } \mathrm{t} \\
\mathrm{e}_{\mathrm{t}}=\mathrm{K}_{\mathrm{t}}-\mathrm{a}_{1}-\mathrm{a}_{2} \mathrm{~S}_{\mathrm{t}} & \begin{array}{l}
\mathrm{S}_{\mathrm{t}}=\text { price of Falta market at period } \mathrm{t} \\
\Delta \mathrm{K}_{\mathrm{t}}=\text { change in price of Bhangore-II market } \\
\text { period } \mathrm{t}
\end{array} \\
\Delta \mathrm{Kt}=\theta_{1} \Delta \mathrm{S}_{\mathrm{t}}+\theta_{2} \mathrm{e}_{\mathrm{t}}-1+\mathrm{e}_{\mathrm{t}} & \\
\Delta \mathrm{Kt}=\theta_{0}+\theta_{1} \Delta \mathrm{S}_{\mathrm{t}}+\theta_{2}\left(\mathrm{~K}_{\mathrm{t}}-\mathrm{a}_{2} \mathrm{~S}_{\mathrm{t}}\right)-1+\mathrm{e}_{\mathrm{t}} & \\
\text { Where, } \theta_{0}=-\mathrm{a}_{1} \text { and } \mathrm{a}_{1}, \mathrm{a}_{2}, \theta_{1}, \theta_{2} \text { are intercept, } \theta_{2} \text { is the speed of adjustment }
\end{array}
$$




\section{Impulse response}

It was important to know, how the markets behave when there is a shock given to the error term in the co-integrating function. To analyze this, the impulse response analysis was conducted, where one SD shock was given to the error term and how long markets required stabilizing the price. Bhangore-II market is a function of the previous lag period price of Bhangore-II as well as lag price of Falta market.

$\mathrm{Kit}=\mathrm{a} 1 \mathrm{St}-1+\mathrm{a} 12 \mathrm{Kt}-1+\mathrm{e} 1 \mathrm{t} \mathrm{Kit}=$ price of the Bhangore-II market at $\mathrm{t}$ period Sit $=\mathrm{a} 21 \mathrm{Kt}-$ $1+\mathrm{a} 22 \mathrm{St}-1+\mathrm{e} 2 \mathrm{tSit}=$ price of Falta market at period $\mathrm{t}$

Kt-1= one year lag price of Bhangore-II market

The error term is the causal factor for the uncertainties of price in Bhangore-II for a particular vegetable. The error term is derived from the uncontrolled factors leading to price fluctuation.

\section{Results and Discussion}

\section{Stationary test and co-integration analysis}

A multivariate co-integration technique was employed to study the price interdependence rather than estimating just structural relationship between prices. The cointegration methodology applied hereto capture long run properties, when dealing with non- stationary data. Testing for cointegration at the first step requires testing the order of stationary of the variables. The order of integration (existence or absence of nonstationary) in the time series was tested to find the unit root by Dickey Fuller test (ADF). The result of unitroot test of Tomato, Cauliflower, Cabbage, Cucurbits, Chili and Brinjal prices were documented (Table 2 and
3). Augmented Dickey Fuller (ADF) test for Tomato, Cauliflower, Cabbage, Cucurbits, Chili and Brinjal indicated that all the variables are non-stationary in the levels. The first difference or integrated order 1 denoted as I (1) of all the price series in first period (2017-2018) were found to be stationary, The non stationary series of all other price series were tested for the period 2017 and 2018 and found that these prices were stationary at the first difference or I (1), order of integration and contained a unit root.

In the present study efficacy of APMC vegetable markets of South 24 Parganas in a co- integration framework using Johansen's maximum likelihood procedure using the weekly price data for Tomato, Cauliflower, Cabbage, Cucurbits, Chili, and Brinjal from ten APMC markets has been examined. Vector Auto regressions (VAR) were run to determine the relationship among the prices of Baruipur, Budge Budge-II, Bhangore-II, Diamond Harbour-I and Falta markets for the periods (2017 and 2018).

It was seen that the price series from all ten major markets of vegetables are I (1) i.e., stationary after first difference. However, there may, still exist stochastic trends that all price series share. An equilibrium relationship was approximated by estimating a stationary linear combination(s) using the Johansen cointegration test. The long run association through the co- integration analysis showed the relationship between the prices of different markets.

Co-integration model explained (R2) more than $60 \%$ of price variation in all the market except Budge Budge-II (Table 4 and 5). It was observed that may important markets such as Bhangore-II, Budge Budge-II have integrated with the lag price of Baruipur and Falta markets. Similarly at Falta, Diamond Harbour-I and Baruipur, Tomato price 
associated with lag price of Bhangore- II and Budge Budge- II.

Tomato price of Bhangore-II is associated with the lag price of Budge Budge-II. Other markets did not show strong integration with the lag price of the other markets. Both the table showed the existence of integration in the selected market pair but was not very high. Thakur (1994) had also reported that the total costs as well as the margins were highest for tomato followed by cauliflower, cabbage and peas. However, Kumar et al., (2002) have observed that peas gave a higher net return over variable costs.

Important markets such as Bhangore-II, Budge Budge-II have integration with the lag price of Baruipur and Falta markets (Table 6 and 7). Similarly at Falta, Diamond Harbour-I and Baruipur, Tomato price associated with lag price of Bhangore-II, Budge Budge-II. Cauliflower price of Bhangore-II market is associated with the lag price of Budge BudgeII. Other markets did not show strong integration with the lag price of the other markets. None of the market pairs were per perfectly integrated. The integration of Cauliflower prices in different markets between two periods shows improvement in integration of markets over time.

From the table (Table 8 and 9) showed that co-integration model explained (R2) more than $70 \%$ of price variation in all the markets in the second period (2018). It can be conclude that important markets such as Bhangore-II, Budge Budge-II have integration with the lag price of Baruipur and Falta markets. Similarly at Falta, Diamond Harbour-I and Baruipur, Tomato price associated with lag price of Bhangore-II and Budge Budge-II. Cabbage price of BhangoreII market is associated with the lag price of Budge Budge-II. Other markets did not any show strong integration with the lag price of the other markets. None of the market pairs were per perfectly integrated. If we compare the integration of Cauliflower prices in different markets between two periods, showed that the integration has increased in the second period (2018).

It was observed that important Cucurbits markets such as Bhangore-II, Budge Budge-II have integration with the lag price of Baruipur and Falta markets. Similarly at Falta, Diamond Harbour-I and Baruipur, Tomato price associated with lag price of Bhangore-II and Budge Budge-II blocks. It can be revealed that from the experiment that Cucurbits price in the block Bhangore-II was associated with the lag price of Budge BudgeII (Table 10and 11). Other markets did not show strong integration among themselves. The value of all the selected markets pairs of South 24 Parganas were positive and ranged between 0.16 to 0.99 . There is existence of integration in the selected Cucurbits market pair but were not very high. The integration of Cucurbits prices in different markets between i.e., 2017 and 2018 the integration has increased in the second period.

From the experiment conferred that cointegration model explained (R2) more $75 \%$ of price variation in all the markets except Budge Budge- II market. It is observed that many important markets such as Bhangore-II, Budge Budge-II have integrated with the lag price of Baruipur and Falta markets. Similarly, in the blocks of Falta, Diamond Harbour-I and Baruipur, Tomato price associated with lag price of Bhangore-II and Budge Budge-II blocks (Table 12 and 13). Chili price of Bhangore-II block is associated with the lag price of Budge Budge-II. Other markets did not show strong integration with the lag price. The values of all the selected markets pairs of West Bengal were positive. This showed the existence of integration in the selected market pair but was not very 
high. The integration of Chili prices in different markets between two periods, the integration has increased in the second period (2018). Singh et al., (2001) have studied in the marketing of chilies have identified the three different channels and worked out that the price spread and farmers share of the consumer's rupee. They have found out that the price spread indicate that the intermediaries present in the marketing channel charge a high margin of profit as compared to the service they have rendered.

From the tables (Table 14 and 15) showed that Co-integration model for Brinjal explained (R2) more than $75 \%$ of price variation in all the markets. It is observed that many important markets such as Bhangore-II, Budge Budge-II have integration with the lag price of Baruipur, Falta and Diamond Harbour-I markets. Similarly in the blocks of Falta, Diamond Harbour-I and Baruipur, Brinjal price associated with lag price of Bhangore-II, Budge Budge-II. Brinjal price in the block Bhangore-II is associated with the lag price of Budge Budge-II. Other markets did not show strong integration with their lag prices. There is existence of integration in the selected market pairs. None of the market pairs were per perfectly integrated. If we compare the integration of Brinjal prices in different markets between two periods, the integration has improved in the second period.

\section{Speed of adjustment}

The speed of adjustment for achieving long run equilibrium, vector autoregressive (VAR) process, was analyzed. Long run equilibrium relationships between these prices were also observed. For this, the error term can be treated as equilibrium error and also the intertwined relationship in the short run giving way to a long run association. The error correction mechanism (ECM) was used to estimate the acceleration speed of the short run deviation to the long run equilibrium. It was evident from Table 16, that the error correction term for both Tomato and Cauliflower has exhibited the expected negative sign and strongly indicates the convergence of Bhangore-II, Baruipur, Falta, Budge Budge-II and Diamond Harbour-I town prices in the long run. The estimated coefficients of error correction were - 0.07, 0.08, -0.06, -0.14 and -0.06 for Bhangore-II, Baruipur, Falta, Budge Budge-II and Diamond Harbour-I town price respectively in case of Tomato during first period (2017). The values of coefficients have increased during second period $(-0.11,-0.18,-0.39$, 0.21 and - 0.08). It showed that the speed of adjustment for long run equilibrium was higher in the second period. In case of Cauliflower, the absolute values of coefficients for residual for Bhangore-II, Baruipur, Falta, Budge Budge-II and Diamond Harbour-I town price has increased from $-0.39,-0.34,-0.17,-0.11$ and -0.17 to $0.44,-0.40,-0.25,-0.14$ and -0.51 for first and second period, respectively showing the same trend as in case of Tomato. These coefficients expressed the percentage by disequilibrium adjusted in time period i.e., a week's time.

It is evident from the Table 17, the error correction term for both Cabbage and Cucurbits has exhibited the expected negative sign and strongly indicates the convergence of Bhangore-II, Budge Budge-II, Diamond Harbour-I town, Baruipur and Falta prices in the long run. The estimated coefficients of error correction for cabbage markets were $0.04,-0.02,-0.09,-0.12$ and -0.02 for Bhangore-II, Budge Budge-II, Diamond Harbour-I town, Baruipur and Falta price, respectively during first period (2017). These values of coefficients have increased during second period $(-0.65,-0.37,-0.68,-0.28$, 0.18 ). It showed that the speed of adjustment for long run equilibrium was higher in the second period (2018). In case of Cucurbits, 
the absolute values of coefficients for residual for Cucurbits price in Bhangore-II, Falta, Diamond Harbour-I town, Baruipur and Budge Budge-II has increased from -0.08, $0.04,-0.07,-0.05,-0.06$ in the first period (2017) to $-0.10,-0.06,-0.30,-0.18$ and -0.11 in the second period (2018) respectively showing the same trend as in case of cabbage. The coefficients of the lag residual were found to be negative as desired. These coefficients are referred to as the speed of adjustment (converging) factors and measure the short run deviation from the long run equilibrium. It was evident from the Table 18, that the error correction term for both Chili and Brinjal has exhibited the expected negative sign and strongly indicates the convergence of Bhangore-II, Budge Budge-II, Diamond Harbour-I town, Baruipur and Falta prices in the long run. The estimated coefficients of error correction were -0.04 , $0.05,-0.11,-0.07$ and -0.15 for Bhangore-II, Budge Budge-II, Diamond Harbour-I, Baruipur and Falta market price, respectively in case of Chili during first period (2017). The values of coefficients have increased during second period $(-0.25,-0.09,-0.08,-0.14$ and $0.24)$. It showed that the speed of adjustment for long run equilibrium was higher in the second period (2018). In case of Brinjal, the absolute values of coefficients of residual for Brinjal price in Bhangore-II, Bruipur, Falta, Budge Budge-II and Diamond Harbour-I town has increased from $-0.09,-0.10,-0.21$, $0.14,-0.13$ in the first period (2017) to -0.25 , $-0.21,-0.25,-0.15$ and -0.23 in the second period (2018) respectively showing the same trend as in case of Chili.

Table.1 Various market of different potential block of South 24 Parganas in the year of 2017-2018

\begin{tabular}{|c|c|c|}
\hline & Name & Sampling type \\
\hline Selection of District & South 24 Parganas & Purposive Sampling \\
\hline Selection of Block & 5 Blocks & Purposive Sampling \\
\hline Selection of markets & 2 markets of each block ( $2 \times 5=10$ markets $)$ & Purposive Sampling \\
\hline $\begin{array}{l}\text { Selection } \\
\text { respondents }\end{array}$ & $\begin{array}{c}30 \text { respondents of each market } \\
(30 \times 10=300 \text { respondents }) \\
(20 \text { farmers }+5 \text { wholesaler }+5 \text { retailer })\end{array}$ & Purposive Sampling \\
\hline
\end{tabular}

Table.2 Augmented Dickey Fuller test of Tomato, Cauliflower, Cabbage, Cucurbits, Chili and Brinjal price (2017)

t statistic $=2.58$

\begin{tabular}{|c|c|c|c|c|c|c|}
\hline Block & Tomato & Cauliflower & Cabbage & Chili & Cucurbits & Brinjal \\
\hline Baruipur & 10.18 & 8.83 & 9.82 & 8.67 & 8.80 & 7.86 \\
\hline Budge Budge-II & 6.91 & 7.42 & 8.28 & 7.42 & & 7.00 \\
\hline Bhangore-II & 8.03 & 7.62 & 8.53 & 8.49 & 7.50 & 8.37 \\
\hline $\begin{array}{c}\text { Diamond } \\
\text { Harbour- I }\end{array}$ & 7.45 & 7.89 & 8.39 & 8.67 & 8.91 & 9.27 \\
\hline Falta & 8.23 & 6.96 & 8.61 & 9.45 & 4.97 & 8.37 \\
\hline
\end{tabular}

All the coefficients are significant at 10 percent of probability level. 
Table.3 Augmented Dickey Fuller (ADF) test of Tomato, Cauliflower, Cabbage, Cucurbits, Chili and Brinjal price test (2018)

t statistic $=2.58$

\begin{tabular}{|c|c|c|c|c|c|c|}
\hline Block & Tomato & Cauliflower & Cabbage & Chili & Cucurbits & Brinjal \\
\hline Baruipur & 7.45 & 7.89 & 8.39 & 8.67 & 8.91 & 9.27 \\
\hline Budge Budge- II & 7.86 & 7.50 & 8.82 & 8.28 & 8.49 & 7.45 \\
\hline Bhangore- II & 8.83 & 8.92 & 8.67 & 8.80 & 7.89 & 7.86 \\
\hline $\begin{array}{c}\text { Diamond } \\
\text { Harbour- I }\end{array}$ & 8.49 & 7.89 & 8.67 & 8.39 & 8.80 & 7.86 \\
\hline Falta & 8.37 & 7.89 & 8.39 & 4.97 & 9.82 & 7.86 \\
\hline
\end{tabular}

All the coefficients are significant at 10 percent of probability level.

Table.4 Johansson's co-integration regressions for Tomato (2017)

\begin{tabular}{|c|c|c|c|c|c|}
\hline Block & Baruipur & Bhangore-II & Falta & $\begin{array}{l}\text { Budge } \\
\text { Budge-II }\end{array}$ & $\begin{array}{l}\text { Diamond } \\
\text { Harbour-I }\end{array}$ \\
\hline \multirow[t]{2}{*}{ Baruipur (-1) } & 0.30 & 0.38 & 0.25 & 0.12 & 0.10 \\
\hline & $(2.64)$ & $(3.64)$ & $(2.39)$ & $(0.87)$ & $(0.85)$ \\
\hline \multirow[t]{2}{*}{ Baruipur (-2) } & 0.03 & 0.11 & 0.15 & 0.08 & 0.02 \\
\hline & $(0.3)$ & $(0.91)$ & $(1.5)$ & $(0.65)$ & $(0.20)$ \\
\hline \multirow[t]{2}{*}{ Bhangore-II (-1) } & 0.27 & 0.69 & 0.09 & 0.42 & 0.12 \\
\hline & $(2.76)$ & $(6.01)$ & $(0.98)$ & $(4.11)$ & $(1.15)$ \\
\hline \multirow[t]{2}{*}{ Bhangore-II (-2) } & 0.04 & 0.11 & 0.02 & 0.07 & 0.13 \\
\hline & $(0.0)$ & $(0.87)$ & $(0.2)$ & $(0.62)$ & $(1.26)$ \\
\hline \multirow[t]{2}{*}{ Falta (-1) } & 0.26 & 0.29 & 0.58 & 0.16 & 0.28 \\
\hline & $(2.13)$ & $(1.97)$ & $(4.95)$ & (1.13) & $(2.05)$ \\
\hline \multirow[t]{2}{*}{ Falta (-2) } & 0.32 & 0.05 & 0.27 & 0.05 & 0.11 \\
\hline & $(2.43)$ & $(0.37)$ & $(2.13)$ & $(0.36)$ & $(0.75)$ \\
\hline \multirow[t]{2}{*}{ Budge Budge-II (-1) } & 0.24 & 0.45 & 0.02 & 0.49 & 0.14 \\
\hline & $(2.69)$ & $(4.48)$ & $(0.2)$ & $(4.48)$ & $(1.46)$ \\
\hline \multirow[t]{2}{*}{ Budge Budge-II (-2) } & 0.21 & 0.21 & 0.26 & 0.21 & 0.13 \\
\hline & $(2.3)$ & $(0.19)$ & $(1.3)$ & $(1.95)$ & $(1.34)$ \\
\hline \multirow{2}{*}{$\begin{array}{l}\text { Diamond Harbour-I (- } \\
\text { 1) }\end{array}$} & 0.04 & 0.23 & 0.22 & 0.29 & 0.62 \\
\hline & $(0.43)$ & $(1.81)$ & $(2.1)$ & $(0.25)$ & $(5.27)$ \\
\hline \multirow{2}{*}{$\begin{array}{c}\text { Diamond Harbour-I (- } \\
\text { 2) }\end{array}$} & 0.18 & 0.14 & 0.17 & 0.15 & 0.04 \\
\hline & $(0.26)$ & $(1.12)$ & $(1.72)$ & $(1.18)$ & $(0.36)$ \\
\hline R-squared & 0.77 & 0.73 & 0.73 & 0.58 & 0.64 \\
\hline Adj. R-squared & 0.77 & 0.72 & 0.74 & 0.55 & 0.66 \\
\hline
\end{tabular}

Figures in the parentheses are ' $t$ ' values at 5 percent level of significance 
Table.5 Johansson's co-integration regressions for Tomato (2018)

\begin{tabular}{|c|c|c|c|c|c|}
\hline Block & Baruipur & $\begin{array}{c}\text { Bhangore- } \\
\text { II }\end{array}$ & Falta & $\begin{array}{l}\text { Budge } \\
\text { Budge-II }\end{array}$ & $\begin{array}{l}\text { Diamond } \\
\text { Harbour-I }\end{array}$ \\
\hline \multirow[t]{2}{*}{ Baruipur (-1) } & 0.50 & 0.57 & 0.46 & 0.38 & 0.59 \\
\hline & $(5.61)$ & $(5.57)$ & $(4.42)$ & $(3.78)$ & $(5.96)$ \\
\hline \multirow[t]{2}{*}{ Baruipur (-2) } & 0.25 & 0.15 & 0.24 & 0.40 & 0.113 \\
\hline & $(1.96)$ & $(1.07)$ & (1.56) & $(2.73)$ & $(1.10)$ \\
\hline \multirow[t]{2}{*}{ Bhangore-II (-1) } & 0.25 & 0.68 & 0.51 & 0.62 & 0.98 \\
\hline & $(2.17)$ & $(5.55)$ & $(0.80)$ & $(6.09)$ & $(1.10)$ \\
\hline \multirow[t]{2}{*}{ Bhangore-II (-2) } & 0.12 & 0.027 & 0.220 & 0.100 & 0.20 \\
\hline & $(1.08)$ & $(0.22)$ & (1.63) & $(0.78)$ & $(2.11)$ \\
\hline \multirow[t]{2}{*}{ Falta $(-1)$} & 0.29 & 0.15 & 0.51 & 0.186 & 0.131 \\
\hline & $(1.00)$ & $(1.50)$ & $(4.49)$ & $(1.70)$ & (1.74) \\
\hline \multirow[t]{2}{*}{ Falta (-2) } & 0.07 & 0.80 & 0.03 & 0.54 & 0.108 \\
\hline & $(0.80)$ & $(0.80)$ & $(0.26)$ & $(2.50)$ & (1.46) \\
\hline \multirow[t]{2}{*}{ Budge Budge-II (-1) } & 0.24 & 0.29 & 0.21 & 0.35 & 0.10 \\
\hline & $(2.57)$ & $(2.98)$ & (2.06) & $(3.30)$ & $(1.40)$ \\
\hline \multirow[t]{2}{*}{ Budge Budge-II (-2) } & 0.11 & 0.037 & 0.35 & 0.29 & 0.39 \\
\hline & $(1.25)$ & $(0.37)$ & $(0.85)$ & $(1.02)$ & $(0.53)$ \\
\hline \multirow[t]{2}{*}{ Diamond Harbour-I (-1) } & 0.50 & 0.19 & 0.27 & 0.135 & 0.47 \\
\hline & $(0.69)$ & $(1.25)$ & $(1.52)$ & $(0.80)$ & $(4.08)$ \\
\hline \multirow[t]{2}{*}{ Diamond Harbour-I (-2) } & 0.20 & 0.193 & 0.78 & 0.183 & 0.25 \\
\hline & $(1.36)$ & $(1.20)$ & (1.43) & $(1.07)$ & $(2.12)$ \\
\hline R-squared & 0.67 & 0.69 & 0.72 & 0.61 & 0.73 \\
\hline Adj. R-squared & 0.63 & 0.65 & 0.69 & 0.56 & 0.70 \\
\hline
\end{tabular}

Figures in the parentheses are ' $t$ ' values at 5 percent level of significance 
Table.6 Johansson's co-integration regressions for Cauliflower (2017)

\begin{tabular}{|c|c|c|c|c|c|}
\hline Block & Baruipur & $\begin{array}{c}\text { Bhangore- } \\
\text { II }\end{array}$ & Falta & $\begin{array}{c}\text { Budge } \\
\text { Budge-II }\end{array}$ & $\begin{array}{c}\text { Diamond } \\
\text { Harbour-I }\end{array}$ \\
\hline Baruipur (-1) & 0.42 & 0.19 & 0.15 & 0.14 & 0.09 \\
\hline Baruipur (-2) & $(4.24)$ & $(1.71)$ & $(1.01)$ & $(0.11)$ & $(0.76)$ \\
\hline Bhangore-II (-1) & 0.23 & 0.21 & 0.31 & 0.02 & 0.08 \\
\hline & $(1.91)$ & $(1.82)$ & $(2.04)$ & $(0.19)$ & $(0.67)$ \\
\hline Bhangore-II (-2) & 0.40 & 0.68 & 0.09 & 0.45 & 0.25 \\
\hline & $(2.50)$ & $(6.49)$ & $(0.47)$ & $(2.70)$ & $(1.46)$ \\
\hline Falta (-1) & $(0.7)$ & $(3.20)$ & $(1.64)$ & $(1.31)$ & $(0.84)$ \\
\hline & 0.04 & 0.33 & 0.26 & 0.05 & 0.05 \\
\hline Falta (-2) & $(0.46)$ & $(3.27)$ & $(1.93)$ & $(0.50)$ & $(0.47)$ \\
\hline Budge Budge-II (-1) & 0.02 & 0.20 & 0.41 & 0.19 & 0.04 \\
\hline & $(0.22)$ & $(2.14)$ & $(3.19)$ & $(0.18)$ & $(0.38)$ \\
\hline Budge Budge-II (-2) & 0.09 & 0.35 & 0.42 & 0.50 & 0.11 \\
\hline & $(0.54)$ & $(2.19)$ & $(1.95)$ & $(2.79)$ & $(0.60)$ \\
\hline Diamond Harbour-I (-1) & $(0.03$ & 0.14 & 0.02 & 0.11 & 0.17 \\
\hline & $(0.10$ & $(0.85)$ & $(0.12)$ & $(0.61)$ & $(0.94)$ \\
\hline Diamond Harbour-I (-2) & 0.13 & 0.14 & 0.24 & 0.07 & 0.42 \\
\hline & $(0.85)$ & $(0.67)$ & $(1.90)$ & $(0.72)$ & $(0.46)$ \\
\hline R-squared & 0.85 & 0.92 & 0.79 & 0.90 & 0.88 \\
\hline Adj. R-squared & 0.84 & 0.91 & 0.76 & 0.89 & 0.86 \\
\hline
\end{tabular}

Figures in the parentheses are ' $t$ ' values at 5 percent level of significance 
Table.7 Johansson's co-integration regressions for Cauliflower (2018)

\begin{tabular}{|c|l|c|c|c|c|}
\hline Block & Baruipur & $\begin{array}{c}\text { Bhangore- } \\
\text { II }\end{array}$ & Falta & $\begin{array}{c}\text { Budge } \\
\text { Budge- II }\end{array}$ & $\begin{array}{c}\text { Diamond } \\
\text { Harbour- I }\end{array}$ \\
\hline Baruipur (-1) & 0.55 & 0.25 & 0.04 & 0.08 & 0.12 \\
\hline Baruipur (-2) & $(5.49)$ & $(0.42)$ & $(0.45)$ & $(0.59)$ & $(0.06)$ \\
\hline & 0.14 & 0.17 & 0.14 & 0.21 & 0.08 \\
\hline Bhangore-II(-1) & $(1.29)$ & $(1.48)$ & $(1.52)$ & $(1.70)$ & $(0.48)$ \\
\hline & 0.22 & 0.39 & 0.02 & 0.25 & 0.53 \\
\hline Bhangore-II (-2) & $(1.32)$ & $(3.87)$ & $(0.15)$ & $(1.26)$ & $(2.06)$ \\
\hline & 0.30 & 0.63 & 0.20 & 0.56 & 0.46 \\
\hline Falta (-1) & $(0.18)$ & $(3.58)$ & $(1.39)$ & $(2.97)$ & $(1.87)$ \\
\hline Falta (-2) & 0.42 & 0.26 & 0.90 & 0.31 & 0.97 \\
\hline Budge Budge-II (1) & $(3.24)$ & $(1.87)$ & $(7.73)$ & $(2.05)$ & $(4.84)$ \\
\hline & 0.37 & 0.02 & 0.01 & 0.01 & 0.46 \\
\hline Budge Budge-II (-2) & $(2.72)$ & $(0.15)$ & $(0.11)$ & $(0.07)$ & $(2.19)$ \\
\hline & $(0.34)$ & $(0.29)$ & $(1.31)$ & $(2.96)$ & $(1.29)$ \\
\hline & 0.05 & 0.43 & 0.09 & 0.28 & 0.33 \\
\hline Diamond Harbour- I (-1) & $(0.30)$ & $(2.36)$ & $(0.63)$ & $(1.43)$ & $(1.27)$ \\
\hline & $(1.15)$ & $(0.32)$ & $(0.18)$ & $(0.18)$ & $(1.42)$ \\
\hline Diamond Harbour- I (-2) & 0.02 & 0.03 & 0.02 & 0.01 & 0.09 \\
\hline R-squared & $(0.29)$ & $(0.34)$ & $(0.32)$ & $(0.10)$ & $(0.69)$ \\
\hline Adj. R-squared & 0.87 & 0.88 & 0.88 & 0.86 & 0.75 \\
\hline (1) & 0.85 & 0.86 & 0.87 & 0.84 & 0.72 \\
\hline
\end{tabular}

Figures in the parentheses are ' $t$ ' values at 5 percent level of significance 
Table.8 Johansson's co-integration regressions for Cabbage (2017)

\begin{tabular}{|c|c|c|c|c|c|}
\hline Block & $\begin{array}{c}\text { Budge } \\
\text { Budge-II }\end{array}$ & $\begin{array}{c}\text { Diamond } \\
\text { Harbour-I }\end{array}$ & Baruipur & $\begin{array}{c}\text { Bhangore- } \\
\text { II }\end{array}$ & Falta \\
\hline Budge Budge-II (-1) & 0.66 & 0.12 & 0.27 & 0.11 & 0.19 \\
\hline & $(5.09)$ & $(0.81)$ & $(1.63)$ & $(0.71)$ & $(0.01)$ \\
\hline Budge Budge-II (-2) & 0.07 & 0.07 & 0.02 & 0.07 & 0.07 \\
\hline Diamond Harbour-I (-1) & $(0.57)$ & $(0.05)$ & $(0.14)$ & $(0.50)$ & $(0.49)$ \\
\hline & 0.14 & 0.56 & 0.03 & 0.31 & 0.05 \\
\hline Diamond Harbour-I (-2) & $(1.38)$ & $(4.71)$ & $(0.26)$ & $(2.63)$ & $(0.48)$ \\
\hline & 0.02 & 0.20 & 0.05 & 0.06 & 0.09 \\
\hline Baruipur (-1) & $(0.26)$ & $(1.56)$ & $(0.40)$ & $(0.47)$ & $(0.07)$ \\
\hline & 0.08 & 0.06 & 0.29 & 0.25 & 0.11 \\
\hline Baruipur (-2) & $(0.85)$ & $(0.57)$ & $(2.28)$ & $(2.13)$ & $(1.00)$ \\
\hline & 0.20 & 0.07 & 0.01 & 0.19 & 0.35 \\
\hline Bhangore-II (-1) & $(1.89)$ & $(0.05)$ & $(0.12)$ & $(1.56)$ & $(2.62)$ \\
\hline & 0.05 & 0.18 & 0.17 & 0.49 & 0.14 \\
\hline Bhangore-II (-2) & $(0.56)$ & $(1.57)$ & $(1.37)$ & $(4.18)$ & $(1.27)$ \\
\hline & 0.13 & 0.23 & 0.05 & 0.11 & 0.06 \\
\hline Falta (-1) & $(1.45)$ & $(2.16)$ & $(0.48)$ & $(1.08)$ & $(0.61)$ \\
\hline & 0.15 & 0.06 & 0.17 & 0.16 & 0.50 \\
\hline Falta (-2) & $(1.43)$ & $(0.52)$ & $(1.27)$ & $(1.29)$ & $(4.21)$ \\
\hline & 0.01 & 0.20 & 0.07 & 0.02 & 0.37 \\
\hline R-squared & $(0.17)$ & $(1.54)$ & $(0.52)$ & $(0.16)$ & $(3.00)$ \\
\hline Adj. R-squared & 0.73 & 0.61 & 0.63 & 0.62 & 0.81 \\
\hline & 0.69 & 0.56 & 0.59 & 0.57 & 0.79 \\
\hline
\end{tabular}

Figures in the parentheses are ' $t$ ' values at 5 percent level of significance. 
Table.9 Johansson's co-integration regressions for Cabbage (2018)

\begin{tabular}{|c|c|c|c|c|c|}
\hline Block & $\begin{array}{c}\text { Budge } \\
\text { Budge-II }\end{array}$ & $\begin{array}{c}\text { Diamond } \\
\text { Harbour-I }\end{array}$ & Baruipur & $\begin{array}{c}\text { Bhangore- } \\
\text { II }\end{array}$ & Falta \\
\hline Budge Budge- II (-1) & 0.50 & 0.47 & 0.28 & 0.13 & 0.04 \\
\hline & $(3.91)$ & $(0.28)$ & $(2.00)$ & $(0.98)$ & $(0.29)$ \\
\hline Budge Budge- II (-2) & 0.07 & 0.07 & 0.05 & 0.05 & 0.06 \\
\hline & $(0.58)$ & $(0.47)$ & $(0.03)$ & $(0.43)$ & $(0.04)$ \\
\hline Diamond Harbour-I (-1) & 0.03 & 0.04 & 0.88 & 0.011 & 0.54 \\
\hline & $(0.40)$ & $(0.34)$ & $(2.85)$ & $(0.11)$ & $(0.52)$ \\
\hline Diamond Harbour-I (-2) & 0.06 & 0.04 & 0.08 & 0.03 & 0.01 \\
\hline & $(0.69)$ & $(0.38)$ & $(0.84)$ & $(0.36)$ & $(0.10)$ \\
\hline Baruipur (-1) & 0.14 & 0.13 & 0.37 & 0.33 & 0.23 \\
\hline & $(1.13)$ & $(0.80)$ & $(2.75)$ & $(2.66)$ & $(1.71)$ \\
\hline Baruipur (-2) & 0.47 & 0.10 & 0.11 & 0.04 & 0.07 \\
\hline & $(0.03)$ & $(0.60)$ & $(0.79)$ & $(0.31)$ & $(0.56)$ \\
\hline Bhangore- II (-1) & 0.27 & 0.38 & 0.22 & 0.44 & 0.13 \\
\hline & $(1.91)$ & $(2.01)$ & $(1.41)$ & $(2.99)$ & $(0.81)$ \\
\hline Bhangore- II (-2) & 0.05 & 0.24 & 0.19 & 0.04 & 0.04 \\
\hline & $(0.03)$ & $(1.19)$ & $(1.11)$ & $(0.02)$ & $(0.28)$ \\
\hline Falta (-1) & 0.02 & 0.12 & 0.07 & 0.02 & 0.74 \\
\hline & $(0.19)$ & $(0.75)$ & $(0.56)$ & $(0.17)$ & $(5.29)$ \\
\hline Falta (-2) & 0.05 & 0.20 & 0.19 & 0.05 & 0.01 \\
\hline & $(0.43)$ & $(1.22)$ & $(1.35)$ & $(0.44)$ & $(0.09)$ \\
\hline R-squared & 0.83 & 0.74 & 0.82 & 0.83 & 0.80 \\
\hline Adj- R-squared & 0.81 & 0.71 & 0.80 & 0.81 & 0.77 \\
\hline
\end{tabular}

Figures in the parentheses are ' $t$ ' values at 5 percent level of significance 
Table.10 Johansson's co-integration regressions for Cucurbits (2017)

\begin{tabular}{|c|c|c|c|c|c|}
\hline Block & Falta & $\begin{array}{c}\text { Diamond } \\
\text { Harbour-I }\end{array}$ & Baruipur & $\begin{array}{c}\text { Budge } \\
\text { Budge- II }\end{array}$ & $\begin{array}{c}\text { Bhangore- } \\
\text { II }\end{array}$ \\
\hline \multirow[t]{2}{*}{ Falta $(-1)$} & 0.66 & 0.11 & 0.08 & 0.18 & 0.22 \\
\hline & $(5.69)$ & $(1.26)$ & $(0.76)$ & $(2.07)$ & $(2.24)$ \\
\hline \multirow[t]{2}{*}{ Falta (-2) } & 0.08 & 0.12 & 0.02 & 0.19 & 0.12 \\
\hline & $(0.69)$ & $(1.41)$ & $(0.02)$ & $(2.19)$ & $(1.23)$ \\
\hline \multirow[t]{2}{*}{ Diamond Harbour- I (-1) } & 0.10 & 0.51 & 0.16 & 0.20 & 0.17 \\
\hline & $(0.76)$ & $(4.74)$ & $(1.24)$ & $(1.86)$ & $(1.48)$ \\
\hline \multirow[t]{2}{*}{ Diamond Harbour- I (-2) } & 0.12 & 0.19 & 0.26 & 0.15 & 0.14 \\
\hline & $(0.94)$ & $(1.88)$ & $(1.99)$ & $(1.48)$ & $(1.21)$ \\
\hline \multirow[t]{2}{*}{ Baruipur (-1) } & 0.12 & 0.05 & 0.40 & 0.01 & 0.11 \\
\hline & $(1.06)$ & $(0.06)$ & $(3.74)$ & $(0.20)$ & $(1.11)$ \\
\hline \multirow[t]{2}{*}{ Baruipur (-2) } & 0.09 & 0.08 & 0.17 & 0.09 & 0.01 \\
\hline & $(0.81)$ & $(0.96)$ & $(1.67)$ & $(1.06)$ & $(0.16)$ \\
\hline \multirow[t]{2}{*}{ Budge Budge-II (-1) } & 0.05 & 0.19 & 0.34 & 0.77 & 0.07 \\
\hline & $(0.03)$ & $(1.82)$ & $(2.56)$ & (7.06) & $(0.60)$ \\
\hline \multirow[t]{2}{*}{ Budge Budge-II (-2) } & 0.30 & 0.17 & 0.29 & 0.06 & 0.07 \\
\hline & $(1.95)$ & $(1.48)$ & $(2.00)$ & $(0.51)$ & $(0.54)$ \\
\hline \multirow[t]{2}{*}{ Bhangore-II (-1) } & 0.09 & 0.02 & 0.14 & 0.22 & 0.82 \\
\hline & $(0.72)$ & $(0.20)$ & $(1.18)$ & $(2.25)$ & $(7.28)$ \\
\hline \multirow[t]{2}{*}{ Bhangore-II (-2) } & 0.01 & 0.06 & 0.21 & 0.24 & 0.01 \\
\hline & $(0.14)$ & $(0.06)$ & $(1.69)$ & $(2.37)$ & $(0.09)$ \\
\hline R-squared & 0.74 & 0.74 & 0.79 & 0.84 & 0.85 \\
\hline Adj. R-squared & 0.71 & 0.71 & 0.77 & 0.82 & 0.83 \\
\hline
\end{tabular}

Figures in the parentheses are ' $t$ ' values at 5 percent level of significance 
Table.11 Johansson's co-integration regressions for Cucurbits (2018)

\begin{tabular}{|c|c|c|c|c|c|}
\hline Block & Falta & $\begin{array}{l}\text { Diamond } \\
\text { Harbour- I }\end{array}$ & Baruipur & $\begin{array}{c}\text { Budge } \\
\text { Budge- II }\end{array}$ & $\begin{array}{l}\text { Bhangore- } \\
\text { II }\end{array}$ \\
\hline \multirow[t]{2}{*}{ Falta (-1) } & 0.43 & 0.26 & 0.43 & 0.31 & 0.25 \\
\hline & $(2.72)$ & $(1.90)$ & $(2.42)$ & $(1.37)$ & $(1.61)$ \\
\hline \multirow[t]{2}{*}{ Falta (-2) } & 0.11 & 0.05 & 0.08 & 0.30 & 0.05 \\
\hline & $(0.73)$ & $(0.39)$ & $(0.51)$ & $(1.36)$ & $(0.37)$ \\
\hline \multirow{2}{*}{$\begin{array}{c}\text { Diamond Harbour- I } \\
(-1)\end{array}$} & 0.14 & 0.38 & 0.08 & 0.28 & 0.35 \\
\hline & $(1.02)$ & $(3.01)$ & $(0.51)$ & $(1.35)$ & $(2.52)$ \\
\hline \multirow{2}{*}{$\begin{array}{l}\text { Diamond Harbour-I } \\
(-2)\end{array}$} & 0.14 & 0.25 & 0.05 & 0.26 & 0.19 \\
\hline & $(1.13)$ & $(0.22)$ & $(0.37)$ & $(0.32)$ & $(1.51)$ \\
\hline \multirow[t]{2}{*}{ Baruipur (-1) } & 0.30 & 0.22 & 0.51 & 0.31 & 0.22 \\
\hline & $(2.18)$ & $(1.85)$ & $(3.25)$ & $(1.53)$ & $(1.59)$ \\
\hline \multirow[t]{2}{*}{ Baruipur (-2) } & 0.16 & 0.09 & 0.04 & 0.06 & 0.13 \\
\hline & $(1.17)$ & $(0.75)$ & $(0.26)$ & $(0.32)$ & $(0.98)$ \\
\hline \multirow[t]{2}{*}{ Budge Budge- II (1) } & 0.13 & 0.14 & 0.11 & 0.11 & 0.05 \\
\hline & $(1.51)$ & $(1.85)$ & $(1.06)$ & $(0.88)$ & $(0.61)$ \\
\hline \multirow[t]{2}{*}{ Budge Budge- II (2) } & 0.02 & 0.04 & 0.03 & 0.02 & 0.12 \\
\hline & $(0.26)$ & $(0.48)$ & $(0.34)$ & $(0.21)$ & $(0.13)$ \\
\hline \multirow[t]{2}{*}{ Bhangore- II (-1) } & 0.24 & 0.29 & 0.17 & 0.48 & 0.58 \\
\hline & $(1.40)$ & (1.88) & $(0.86)$ & (1.88) & $(3.35)$ \\
\hline \multirow[t]{2}{*}{ Bhangore- II (-2) } & 0.11 & 0.20 & 0.22 & 0.16 & 0.15 \\
\hline & $(0.65)$ & $(1.32)$ & $(1.11)$ & $(0.62)$ & $(0.88)$ \\
\hline R-squared & 0.94 & 0.94 & 0.91 & 0.87 & 0.93 \\
\hline Adj. R-squared & 0.93 & 0.93 & 0.90 & 0.85 & 0.92 \\
\hline
\end{tabular}

Figures in the parentheses are ' $t$ ' values at 5 percent level of significance. 
Table.12 Johansson's co-integration regressions for Chili (2017)

\begin{tabular}{|c|c|c|c|c|c|}
\hline Block & Bhangore- & $\begin{array}{c}\text { Budge } \\
\text { II }\end{array}$ & $\begin{array}{c}\text { Diamond } \\
\text { Harbour- I }\end{array}$ & Baruipur & Falta \\
\hline Bhangore- II (-1) & 0.29 & 0.14 & 0.11 & 0.21 & 0.13 \\
\hline Bhangore- II (-2) & $(2.45)$ & $(1.13)$ & $(0.79)$ & $(2.11)$ & $(1.31)$ \\
\hline & 0.22 & 0.12 & 0.07 & 0.09 & 0.08 \\
\hline Budge Budge- II (-1) & $(1.83)$ & $(1.04)$ & $(0.78)$ & $(0.84)$ & $(0.69)$ \\
\hline & 0.02 & 0.46 & 0.01 & 0.12 & 0.18 \\
\hline Budge Budge- II (-2) & 0.15 & $(3.06)$ & $(0.09)$ & $(0.86)$ & $(1.26)$ \\
\hline & $(1.04)$ & $(0.11)$ & $(0.71)$ & 0.08 & 0.09 \\
\hline Diamond Harbour- I (-1) & 0.09 & 0.12 & 0.36 & 0.10 & $(0.69)$ \\
\hline & $(0.60)$ & $(0.85)$ & $(2.95)$ & $(0.75)$ & 0.16 \\
\hline Diamond Harbour- I (-2) & 0.21 & 0.02 & 0.07 & 0.02 & 0.01 \\
\hline & $(1.45)$ & $(0.16)$ & $(0.65)$ & $(0.21)$ & $(0.11)$ \\
\hline Baruipur (-1) & 0.24 & 0.11 & 0.20 & 0.27 & 0.18 \\
\hline & $(1.91)$ & $(0.84)$ & $(1.86)$ & $(2.34)$ & $(1.48)$ \\
\hline Baruipur (-2) & 0.10 & 0.03 & 0.15 & 0.14 & 0.13 \\
\hline & $(0.84)$ & $(0.02)$ & $(1.50)$ & $(1.29)$ & $(1.14)$ \\
\hline Falta (-1) & 0.09 & 0.29 & 0.31 & 0.36 & 0.47 \\
\hline Falta (-2) & $(0.63)$ & $(2.01)$ & $(2.68)$ & $(2.74)$ & $(3.46)$ \\
\hline R-squared & 0.06 & 0.02 & 0.05 & 0.06 & 0.05 \\
\hline Adj. R-squared & $(0.45)$ & $(0.01)$ & $(0.44)$ & $(0.50)$ & $(0.35)$ \\
\hline & 0.72 & 0.64 & 0.59 & 0.72 & 0.74 \\
\hline & 0.68 & 0.59 & 0.54 & 0.69 & 0.71 \\
\hline
\end{tabular}

Figures in the parentheses are ' $t$ ' values at 5 percent level of significance 
Table.13 Johansson's co-integration regressions for Chili (2018)

\begin{tabular}{|c|c|c|c|c|c|}
\hline Block & Bhangore- & $\begin{array}{c}\text { Budge } \\
\text { II }\end{array}$ & $\begin{array}{c}\text { Diamond } \\
\text { Budge- II }\end{array}$ & Baruipur- I & Falta \\
\hline Bhangore-II (-1) & 0.33 & 0.13 & 0.50 & 0.20 & 0.16 \\
\hline Bhangore-II (-2) & $(2.05)$ & $(0.22)$ & $(0.59)$ & $(1.14)$ & $(0.91)$ \\
\hline & 0.25 & 0.33 & 0.08 & 0.47 & 0.18 \\
\hline Budge Budge-II (-1) & $(1.72)$ & $(0.59)$ & $(0.51)$ & $(2.81)$ & $(1.06)$ \\
\hline & 0.02 & 0.09 & 0.07 & 0.06 & 0.04 \\
\hline Budge Budge-II (-2) & $(0.80)$ & $(0.90)$ & $(2.20)$ & $(2.02)$ & $(1.40)$ \\
\hline & 0.31 & 0.05 & 0.36 & 0.59 & 0.01 \\
\hline Diamond Harbour-I (-1) & $0.19)$ & $(0.43)$ & $(0.10)$ & $(0.17)$ & $(0.49)$ \\
\hline & $(2.31)$ & $(0.37)$ & $(5.12)$ & $(2.97)$ & 0.47 \\
\hline Diamond Harbour-I (-2) & 0.08 & 0.23 & 0.18 & 0.09 & 0.22 \\
\hline & $(0.66)$ & $(0.47)$ & $(1.25)$ & $(0.65)$ & $(1.53)$ \\
\hline Baruipur (-1) & 0.22 & 0.25 & 0.27 & 0.36 & 0.12 \\
\hline & $(1.76)$ & $(0.54)$ & $(1.94)$ & $(2.60)$ & $(0.90)$ \\
\hline Baruipur (-2) & 0.02 & 0.47 & 0.06 & 0.07 & 0.12 \\
\hline & $(0.17)$ & $(0.97)$ & $(0.44)$ & $(0.49)$ & $(0.84)$ \\
\hline Falta (-1) & 0.65 & 0.44 & 0.45 & 0.44 & 0.88 \\
\hline Falta (-2) & $(5.18)$ & $(0.95)$ & $(3.24)$ & $(3.16)$ & $(6.17)$ \\
\hline R-squared & 0.18 & 0.34 & 0.19 & 0.05 & 0.08 \\
\hline Adj. R-squared & $(1.40)$ & $(0.72)$ & $(1.33)$ & $(0.40)$ & $(0.61)$ \\
\hline (-) & 0.95 & 0.52 & 0.93 & 0.93 & 0.93 \\
\hline & 0.94 & 0.47 & 0.93 & 0.92 & 0.93 \\
\hline
\end{tabular}

Figures in the parentheses are ' $t$ ' values at 5 percent level of significance 
Table.14 Johansson's co-integration regressions for Brinjal (2017)

\begin{tabular}{|c|c|c|c|c|c|}
\hline Block & Baruipur & $\begin{array}{c}\text { Bhangore- } \\
\text { II }\end{array}$ & Falta & $\begin{array}{c}\text { Budge } \\
\text { Budge- II }\end{array}$ & $\begin{array}{c}\text { Diamond } \\
\text { Harbour-I }\end{array}$ \\
\hline \multirow[t]{2}{*}{ Baruipur (-1) } & 0.33 & 0.19 & 0.31 & 0.06 & 0.31 \\
\hline & $(2.59)$ & $(0.17)$ & $(2.61)$ & $(0.52)$ & $(2.69)$ \\
\hline \multirow[t]{2}{*}{ Baruipur (-2) } & 0.03 & 0.03 & 0.19 & 0.20 & 0.10 \\
\hline & $(0.30)$ & $(0.34)$ & $(1.56)$ & $(1.57)$ & $(0.84)$ \\
\hline \multirow[t]{2}{*}{ Bhangore-II (-1) } & 0.31 & 0.64 & 0.09 & 0.11 & 0.08 \\
\hline & $(2.55)$ & $(6.12)$ & $(0.83)$ & $(0.94)$ & $(0.70)$ \\
\hline \multirow[t]{2}{*}{ Bhangore-II (-2) } & 0.16 & 0.04 & 0.17 & 0.13 & 0.04 \\
\hline & $(1.10)$ & $(0.40)$ & $(1.44)$ & $(1.11)$ & $(0.40)$ \\
\hline \multirow[t]{2}{*}{ Falta $(-1)$} & 0.06 & 0.09 & 0.10 & 0.12 & 0.08 \\
\hline & $(0.51)$ & $(0.89)$ & $(0.82)$ & $(0.98)$ & $(0.71)$ \\
\hline \multirow[t]{2}{*}{ Falta (-2) } & 0.10 & 0.23 & 0.09 & 0.05 & 0.05 \\
\hline & $(0.82)$ & $(2.30)$ & $(0.82)$ & $(0.48)$ & $(0.05)$ \\
\hline \multirow[t]{2}{*}{ Budge Budge- II (-1) } & 0.06 & 0.20 & 0.14 & 0.38 & 0.04 \\
\hline & $(0.55)$ & $(1.98)$ & $(1.27)$ & $(3.18)$ & $(0.44)$ \\
\hline \multirow[t]{2}{*}{ Budge Budge- II (-2) } & 0.06 & 0.28 & 0.10 & 0.08 & 0.83 \\
\hline & $(0.54)$ & $(2.79)$ & $(0.85)$ & $(0.71)$ & $(0.07)$ \\
\hline \multirow[t]{2}{*}{ Diamond Harbour-I (-1) } & 0.34 & 0.25 & 0.05 & 0.18 & 0.54 \\
\hline & $(2.77)$ & $(2.39)$ & $(0.42)$ & $(1.48)$ & $(4.72)$ \\
\hline \multirow[t]{2}{*}{ Diamond Harbour-I (-2) } & 0.08 & 0.12 & 0.04 & 0.03 & 0.12 \\
\hline & $(0.65)$ & $(1.12)$ & $(0.34)$ & $(0.30)$ & $(1.05)$ \\
\hline R-squared & 0.81 & 0.82 & 0.80 & 0.80 & 0.81 \\
\hline Adj. R-squared & 0.79 & 0.80 & 0.77 & 0.78 & 0.79 \\
\hline
\end{tabular}

Figures in the parentheses are ' $t$ ' values at 5 percent level of significance 
Table.15 Johansson's co-integration regressions for Brinjal (2018)

\begin{tabular}{|c|c|c|c|c|c|}
\hline Block & Baruipur & Bhangore-II & Falta & $\begin{array}{c}\text { Budge } \\
\text { Budge- II }\end{array}$ & $\begin{array}{c}\text { Diamond } \\
\text { Harbour- I }\end{array}$ \\
\hline Baruipur (-1) & 0.10 & 0.38 & 0.34 & 0.23 & 0.17 \\
\hline Baruipur (-2) & $(0.69)$ & $(2.22)$ & $(2.26)$ & $(1.82)$ & $(1.24)$ \\
\hline Bhangore-II (-1) & 0.14 & 0.21 & 0.19 & 0.19 & 0.14 \\
\hline & $(0.89)$ & $(1.20)$ & $(1.21)$ & $(1.46)$ & $(0.95)$ \\
\hline Bhangore-II (-2) & 0.03 & 0.44 & 0.23 & 0.10 & 0.08 \\
\hline & $(0.37)$ & $(3.87)$ & $(2.34)$ & $(0.12)$ & $(0.88)$ \\
\hline Falta (-1) & $(1.61)$ & $(1.12)$ & $(0.16)$ & $(1.31)$ & $(1.45)$ \\
\hline Falta (-2) & 0.20 & 0.08 & 0.27 & 0.10 & 0.32 \\
\hline & $(1.50)$ & $(0.57)$ & $(2.01)$ & $(0.90)$ & $(2.61)$ \\
\hline Budge Budge- II (-1) & 0.04 & 0.14 & 0.07 & 0.07 & 0.14 \\
\hline & $(0.34)$ & $(1.00)$ & $(0.54)$ & $(0.73)$ & $(1.18)$ \\
\hline Budge Budge- II (-2) & 0.38 & 0.45 & 0.36 & 0.52 & 0.25 \\
\hline & $(2.07)$ & $(2.21)$ & $(1.96)$ & $(3.44)$ & $(1.52)$ \\
\hline Diamond Harbour- I (-1) & 0.05 & 0.53 & 0.28 & 0.36 & 0.14 \\
\hline & $(0.32)$ & $(2.70)$ & $(1.63)$ & $(2.50)$ & $(0.90)$ \\
\hline Diamond Harbour- I (-2) & $(5.45)$ & $(0.82)$ & $(3.04)$ & $(1.37)$ & $(1.10)$ \\
\hline & $(0.64)$ & $(-0.95)$ & $(1.30)$ & $(0.83)$ & $(1.92)$ \\
\hline R-squared & 0.79 & 0.82 & 0.80 & 0.86 & 0.85 \\
\hline Adj. R-squared & 0.77 & 0.80 & 0.78 & 0.85 & 0.83 \\
\hline (2) & -0.16 & 0.20 & 0.10 & 0.27 \\
\hline
\end{tabular}

Figures in the parentheses are ' $t$ ' values at 5 percent level of significance 
Table.16 Speed of adjustment of Tomato and Cauliflower

\begin{tabular}{|c|c|c|c|c|c|}
\hline Crop & \multicolumn{2}{|c|}{ Year } & Crop & \multicolumn{2}{c|}{ Year } \\
\hline Tomato & 2017 & 2018 & Cauliflower & 2017 & 2018 \\
\hline Bhangore-II & -0.07 & -0.11 & Bhangore-II & -0.39 & -0.44 \\
\hline Baruipur & -0.08 & -0.18 & Baruipur & -0.34 & -0.40 \\
\hline Falta & -0.06 & -0.39 & Falta & -0.17 & -0.25 \\
\hline Budge Budge-II & -0.14 & -0.21 & Budge Budge-II & -0.11 & -0.14 \\
\hline Diamond Harbour-I & -0.06 & -0.08 & Diamond Harbour-I & -0.17 & -0.51 \\
\hline
\end{tabular}

Table.17 Speed of adjustment of Cabbage and Cucurbits

\begin{tabular}{|c|c|c|c|c|c|}
\hline Crop & \multicolumn{2}{|c|}{ Year } & Crop & \multicolumn{2}{c|}{ Year } \\
\hline Cabbage & 2017 & 2018 & Cucurbits & 2017 & 2018 \\
\hline Bhangore-II & -0.04 & -0.65 & Bhangore-II & -0.08 & -0.10 \\
\hline Baruipur & -0.02 & -0.37 & Baruipur & -0.04 & -0.06 \\
\hline Falta & -0.09 & -0.68 & Falta & -0.07 & -0.30 \\
\hline Budge Budge-II & -0.12 & -0.28 & Budge Budge-II & -0.05 & -0.18 \\
\hline Diamond Harbour-I & -0.02 & -0.18 & Diamond Harbour-I & -0.06 & -0.11 \\
\hline
\end{tabular}

Table.18 Speed of adjustment of Chili and Brinjal

\begin{tabular}{|c|c|c|c|c|c|}
\hline Crop & \multicolumn{2}{|c|}{ Year } & Crop & \multicolumn{2}{c|}{ Year } \\
\hline Chili & 2017 & 2018 & Brinjal & 2017 & 2018 \\
\hline Bhangore-II & -0.04 & -0.25 & Bhangore-II & -0.09 & -0.25 \\
\hline Baruipur & -0.05 & -0.09 & Baruipur & -0.10 & -0.21 \\
\hline Falta & -0.11 & -0.08 & Falta & -0.21 & -0.25 \\
\hline Budge Budge-II & -0.07 & -0.14 & Budge Budge-II & -0.14 & -0.15 \\
\hline Diamond Harbour-I & -0.15 & -0.24 & Diamond Harbour-I & -0.13 & -0.23 \\
\hline
\end{tabular}


Figure.1 Impulse response of Tomato (2017)

Response of Baruipur to one SD Response of Bhangore- II to one Response of Diamond Harbour- I

Innovations

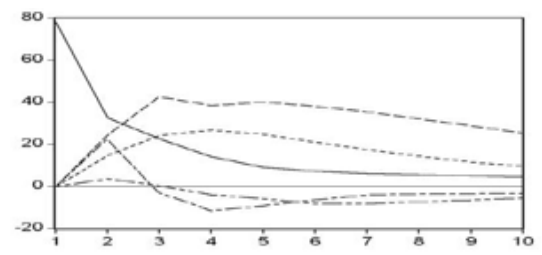

Response of Falta to one SD Innovations

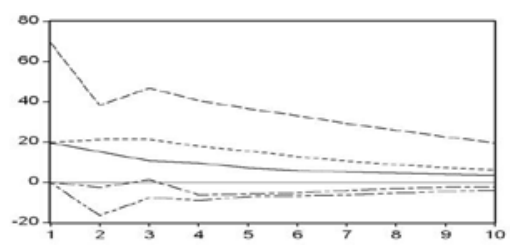

SD Innovations

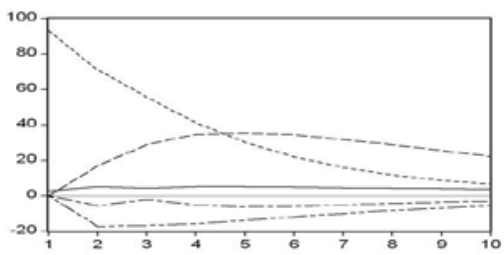

Response of Budge Budge- II to one SD Innovations

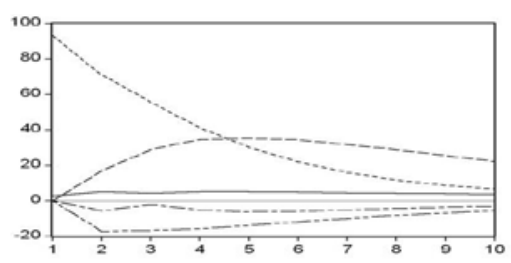

to one SD Innovations

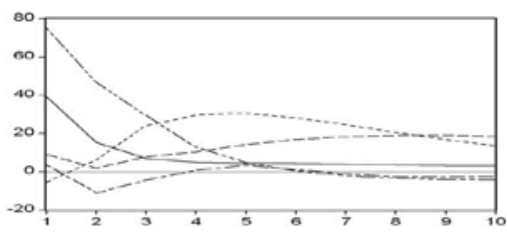

Figure.2 Impulse response of Tomato (2018)

Response of Baruipur to one SD Response of Bhangore- II to one Response of Diamond HarbourInnovations

SD Innovations

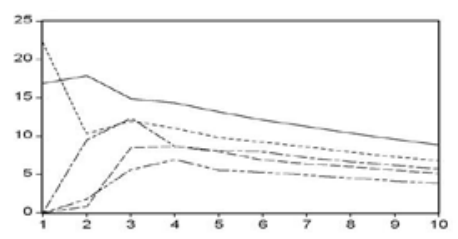

Response of Budge Budge- II to one SD Innovations
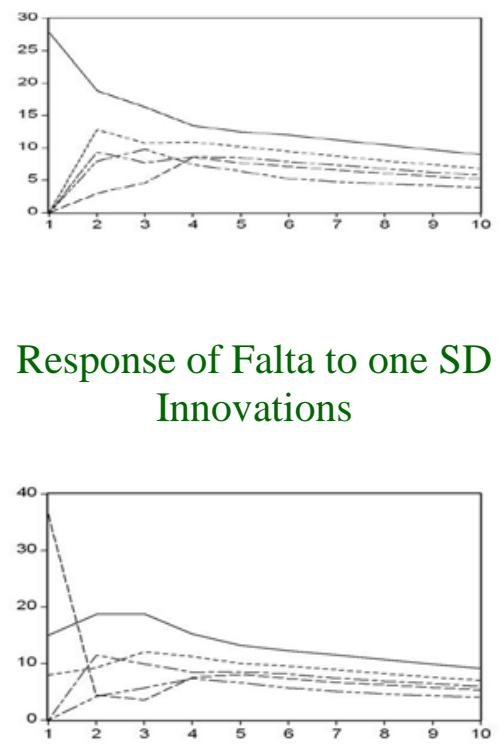

Response of Falta to one SD Innovations

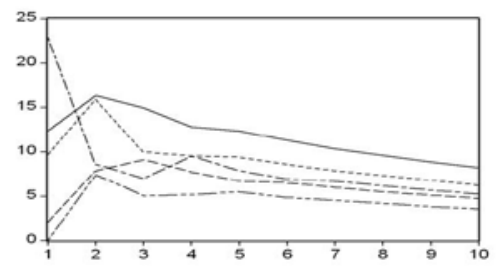

I to one SD Innovations

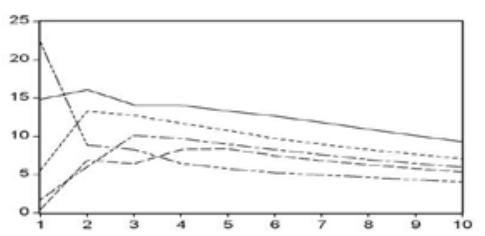


Figure.3 Impulse response of Cauliflower (2017)

Response of Baruipur to one SD Response of Bhangore- II to Response of Diamond Harbour- I Innovations

one SD Innovations

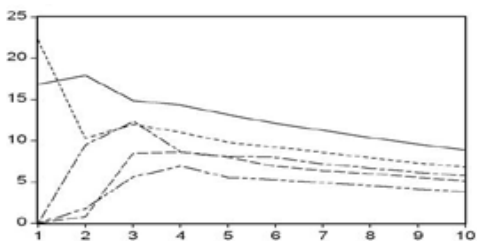

to one SD Innovations

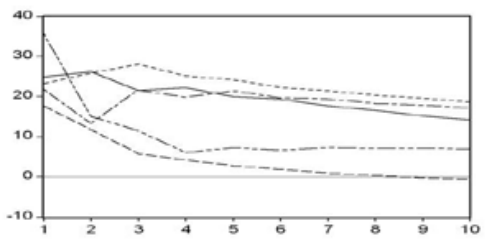

Response of Falta to one SD Response of Budge Budge- II to Innovations

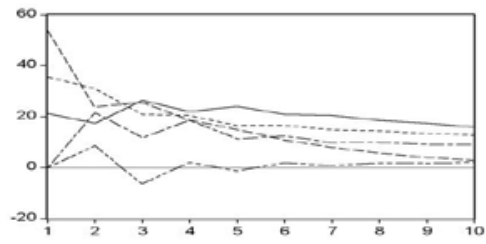
one SD Innovations

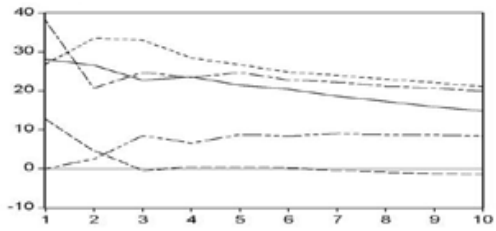

Baruipur

Bhangore -II

Falta

Budge Budge-II

Diamond Harbour-I

Figure.4 Impulse response of Cauliflower (2018)

Response of Baruipur to one SD Innovations

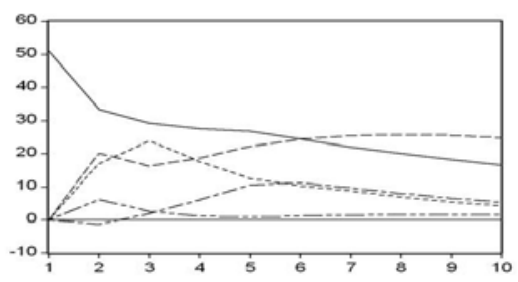

Response of Falta to one SD Innovations

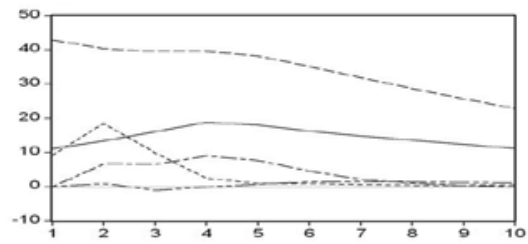

Response of Bhangore- II to one SD Innovations

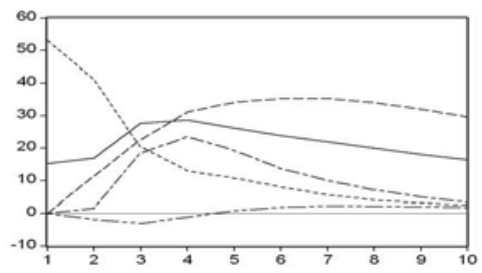

Response of Budge Budge-II to one SD Innovations

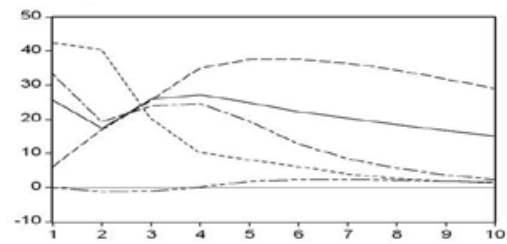

Response of Diamond Harbour- I to one SD Innovations

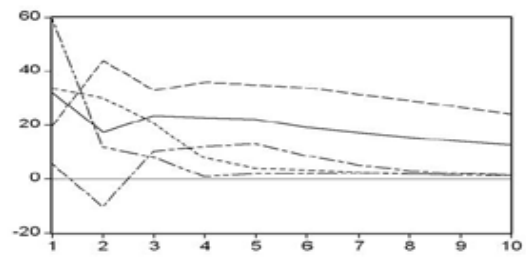

\begin{tabular}{|ll|}
\hline & Baruipur \\
--- & Bhangore- II \\
-- & Falta \\
$\cdots \cdots$. & Budge Budge- II \\
..- & Diamond Harbour- I \\
\hline
\end{tabular}


Figure 5. Impulse response of Cabbage (2017).

Response of Budge Budge-II to Response of Diamond Harbour-

One SD Innovations

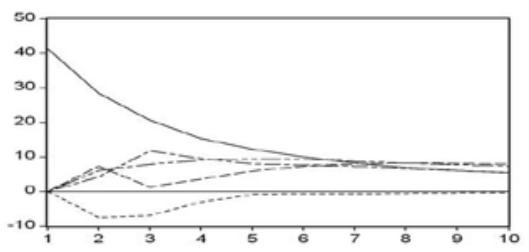

Response of Baruipur to one SD Innovations

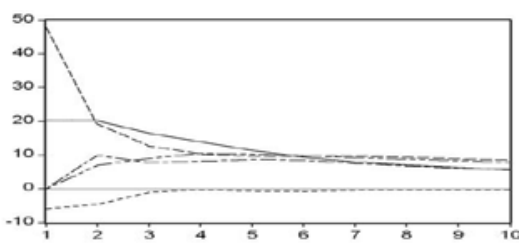

I to one SD Innovations

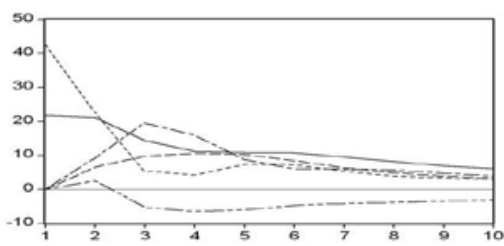

Response of Bhangore II to one

SD Innovations

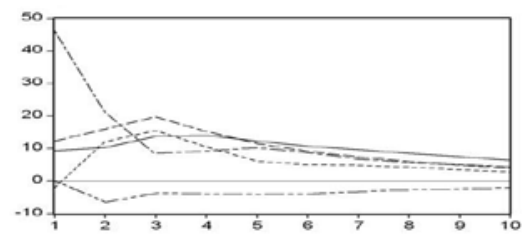

Response of Falta to one SD

Innovations

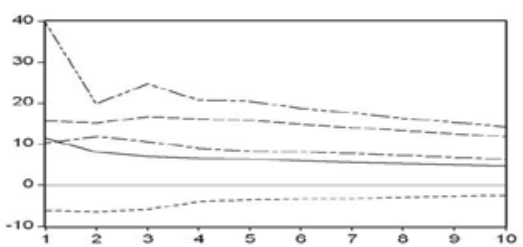

Figure 6. Impulse response of Cabbage (2018).

Response of Budge Budge- II to Response of Diamond Harbour- Response of Falta to one SD one SD Innovations

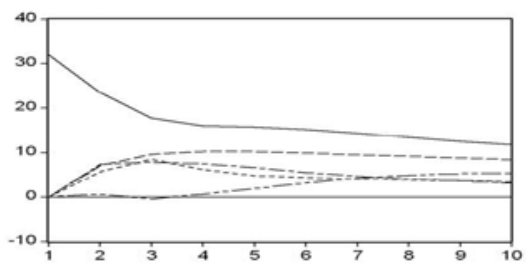

I to one SD Innovations

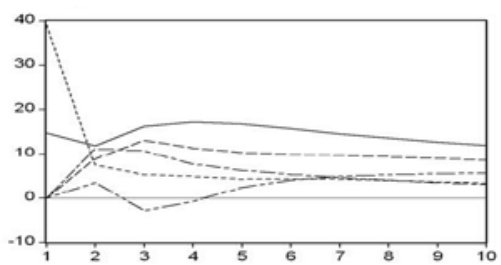

Response of Baruipur to one SD Response of Bhangore-II to one Innovations

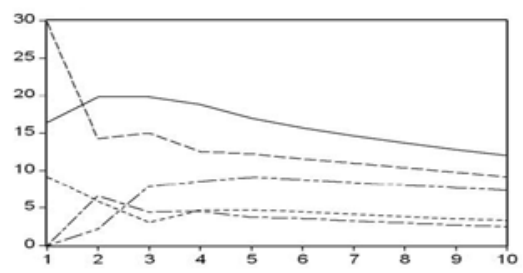

SD Innovations

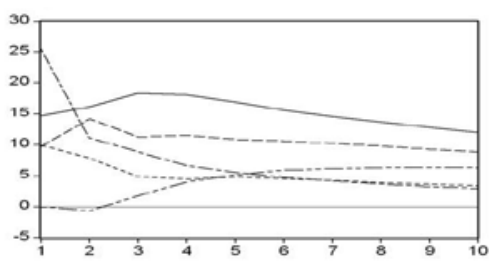

\section{Innovations}

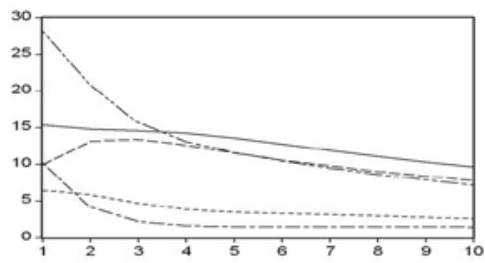


Figure.7 Impulse response of Cucurbits (2017)

Response of Falta to one SD Innovations

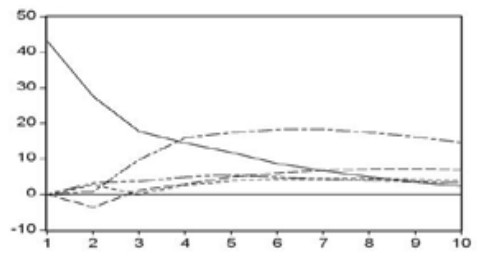

Response of Baruipur to one

SD Innovations

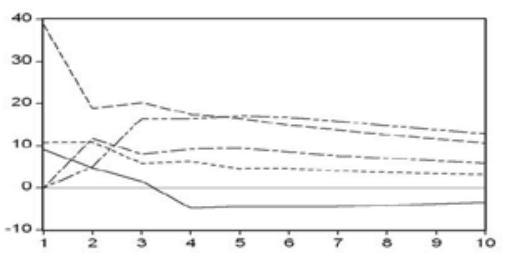

Response of Diamond Harbour- I Response of Bhangore-II to one to one SD Innovations

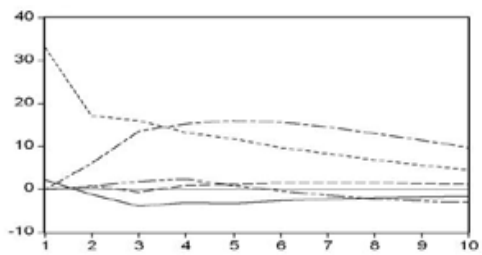

Response of Budge Budge-II to one SD Innovations

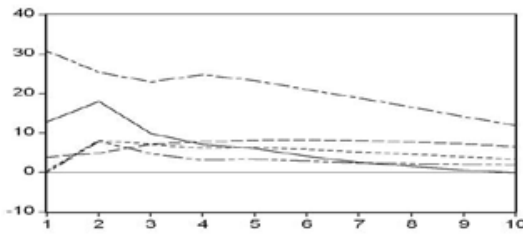

SD Innovations

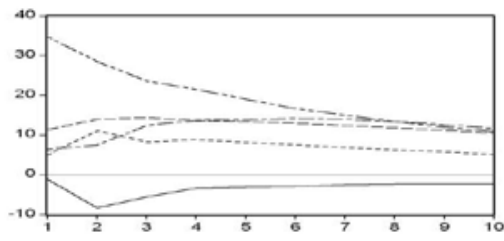

\begin{tabular}{|c|l|}
\hline--- & Falta \\
& Diamond Harbour- I \\
& Baruipur \\
\hline$\ldots . .$. & Budge Budge- II \\
\hline. & Bhangore- II \\
\hline
\end{tabular}

Figure 8. Impulse response of Cucurbits (2018).

Response of Falta to one SD Innovations

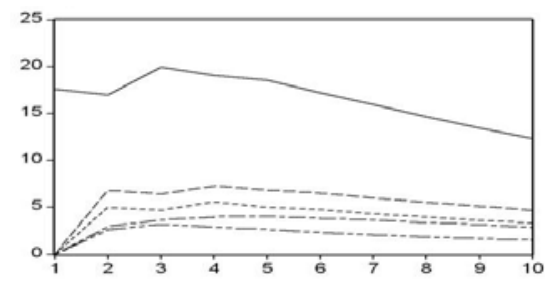

Response of Diamond HarbourI to one SD Innovations

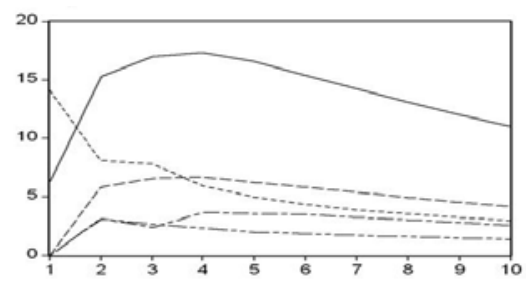

Response of Bhangore-II to one SD Innovations

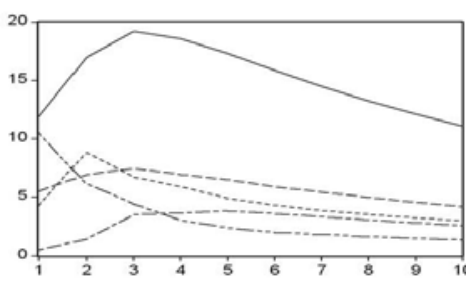

Response of Baruipur to one SD Innovations

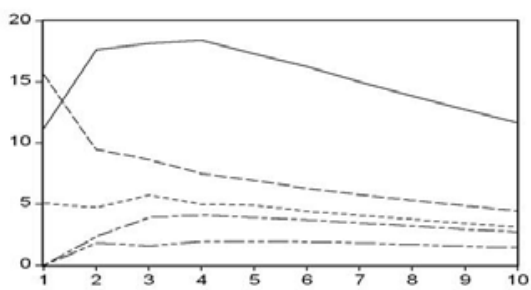

Response of Budge Budge-II to one SD Innovations

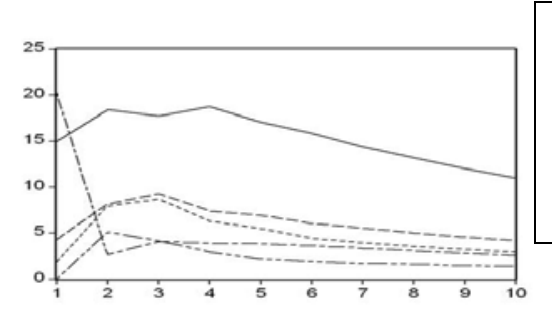


Figure.9 Impulse response of Chili (2017)

Response of Bhangore-II to one Response of Budge Budge-II to SD Innovations

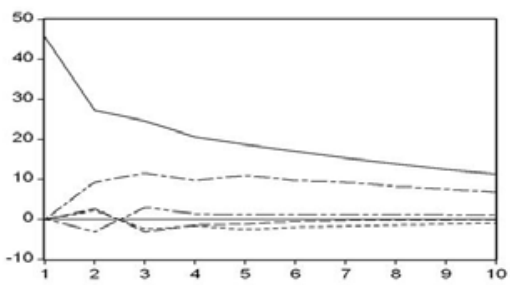

Response of Diamond Harbour- I Response of Baruipur to One to one SD Innovations

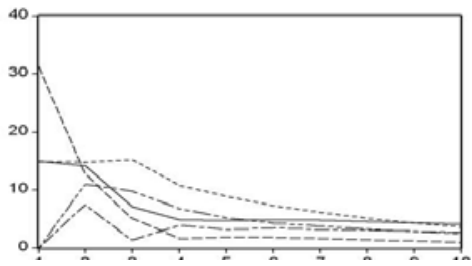
one SD Innovations

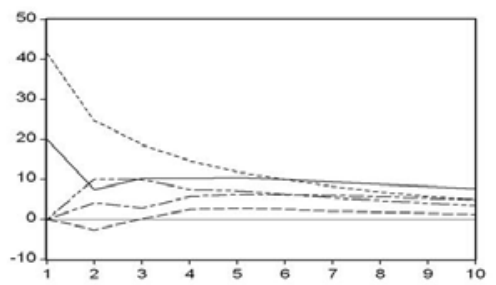

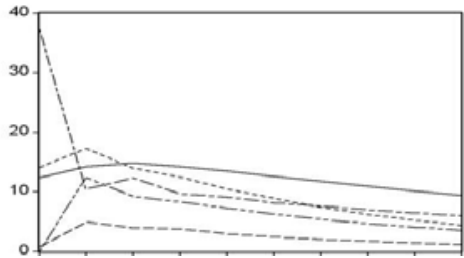

Figure.10 Impulse response of Chili (2018)

Response of Bhangore- II to one SD Innovations

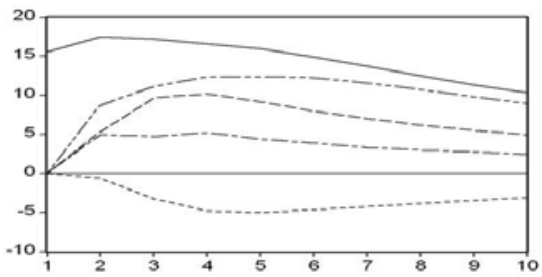

Response of Diamond HarbourI to one SD Innovations

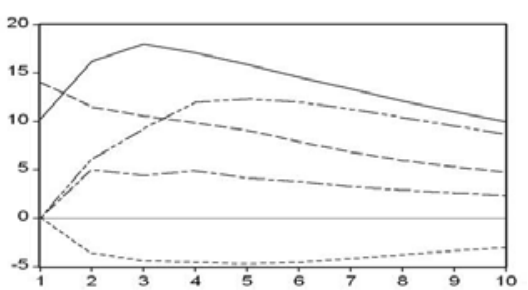

Response of Budge Budge- II to one SD Innovations

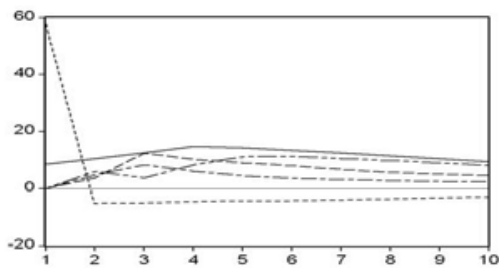

Response of Baruipur to one SD Innovations

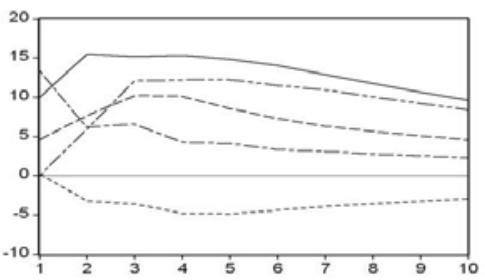

Response of Falta to one SD Innovations

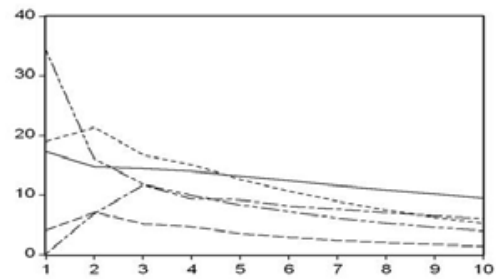

$\begin{array}{cl}- & \text { Bhangore-II } \\ --- & \text { Budge Budge-II } \\ -- & \text { Diamond Harbour-I } \\ \ldots . . . & \text { Baruipur } \\ . .- & \text { Falta }\end{array}$


Figure.11 Impulse response of Brinjal (2017).

Response of Baruipur to one SD Innovations

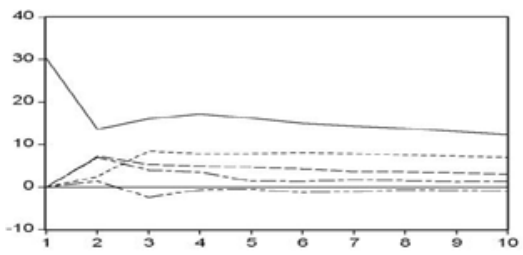

Response of Falta to one SD Innovations

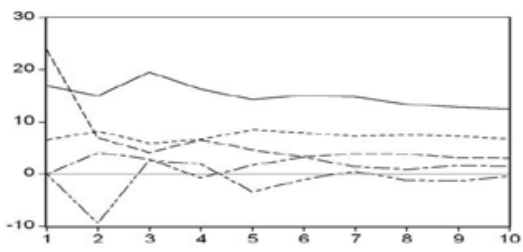

Response of Bhangore-II to one SD Innovations

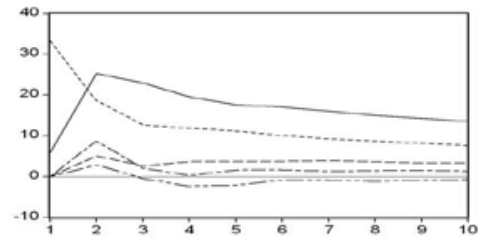

Response of Budge Budge- II to one SD Innovations

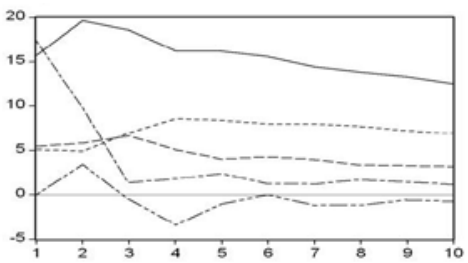

Response of Diamond HarbourI to one SD Innovations

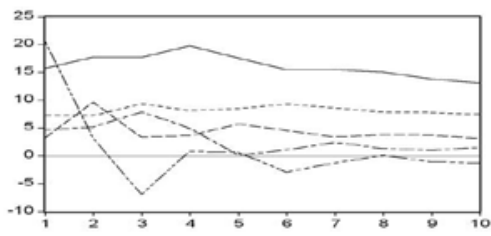

Figure.12 Impulse response of Brinjal (2018)

Response of Baruipur to one SD Response of Bhangore-II to one Response of Diamond Harbour- I Innovations

SD Innovations

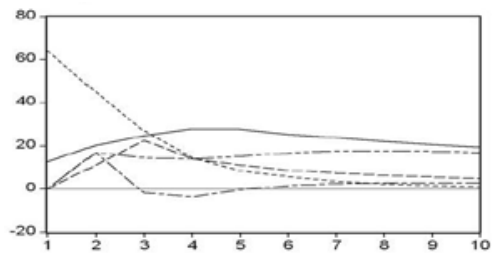

Response of Budge BudgeII to one SD Innovations

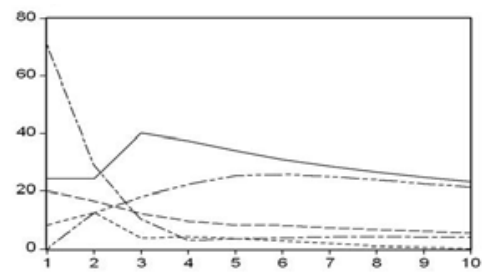

to one SD Innovations

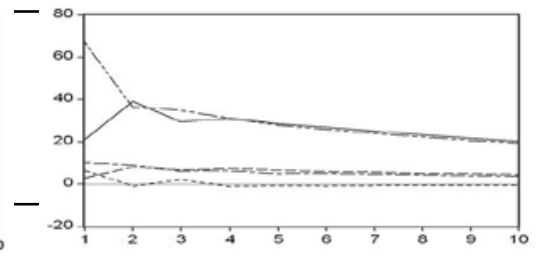




\section{Impulse response}

An impulse response function traces the response of the endogenous variables to one standard deviation (SD) shock or change to one of the disturbance terms in the system. A shock to a variable is transmitted to all of the endogenous variables through the dynamic structure of Vector Autoregressive. To find out the stabilization of the markets every crop of each block one standard deviation shock was given to the random term often called innovation (Figure 1 and 2) from the year round data of two consecutive years (2017 and 2018), it can be revealed that the markets of cauliflower stable within four to five weeks in the year of 2017 (Figure 3) where as in second period (2018), the cauliflower markets stable within three to four weeks (Figure 4). Same type reflected of market picture also denoted in other crops $i$. $e$., in case of Cabbage (Figure 5 and 6), Cucurbits (Figure 7 and 8), Chili (Figure 9 and 10) and Brinjal (Figure 11 and 12) also. Thus it was observed from impulse response analysis that one standard deviation was given one week earlier in the year 2018 as compared to the previous year (2017).

\section{References}

Behura, D. and Pradhan, D.C. 1998. Co integration and Market Integration: An application to the Marine Fish Markets in Orissa. Indian J. Agric. Econ., 53: 344-350.

Goodwin, B.K. and Schroeder, T.C. 1991. Co integration tests and spatial price linkages in regional cattle markets. Am. J. Agr. Econ., 73:452-464.

Kalloo, G. and Pandey, A.K. 2002. Vegetable production - Commendable progress in research. The Hindu Survey of Indian Agriculture. pp. 159-163.

Kumar, A., Sharma, S.K. and Vashist, G.D. 2002. Vegetable farming holds potential in hills: A case study of Kullu region of Himachal Pradesh. Bihar J. Agril. Mar., 10 (4): 355-361.

Murthi, G.S.R. and Shikamany, S.D. 2007. Marketing Reforms are Critical. The Hindu Survey of Indian Agriculture. pp. 107-111.

Nawadkar, D.S. 2005. Marketing of Mangoes grown Around Pune city, Agricultural Situation in India. pp. 265.

Rai, M. and Pandey, A.K. 2004. Hybrid vegetables - Meeting global trade. The Hindu Survey of Indian Agriculture. pp. 129-131.

Singh, H.P. Nath Prem., Dutta, O.P. and Sudha M. 2004. State of the Indian Farmer: A Millennium StudyHorticulture Development (Vol.11), Department of Agriculture and Cooperation, Ministry of Agriculture, Government of India, Academic Foundation, New Delhi.

Thakur, D.S. Sanjay, D.R. and Sharma, K.D. 1994. Economics of off season vegetable production and marketing in hills. Indian J. Agril. Mar. 8: 72- 82.

\section{How to cite this article:}

Prasenjit Kundu, Nayan Kishor Adhikary, Arindam Banerjee and Tapan Mandal. 2020. An Analysis on Extent of Integration and the Speed of Adjustment of Price for Equilibrium and Impulse Response Function in Major Vegetable Markets in West Bengal, India. Int.J.Curr.Microbiol.App.Sci. 9(08): 474-501. doi: https://doi.org/10.20546/ijcmas.2020.908.056 